\title{
Geoecological assessment methods of the radiation hazard of the use of rocks in the building materials industry
}

\author{
Daria Buzina* and Igor Engovatov \\ Moscow State University of Civil Engineering, Yaroslavskoe shosse, 26, Moscow, 129337, Russia
}

\begin{abstract}
The production of human activity has led to the formation of technogenic radiation background, which is formed in its habitat due to initially distributed in the structures of the earth, particularly in rocks, "eternal" natural radionuclides (NRN). In its turn, rocks are the main raw material for building materials and products from them. Natural radionuclides are a source of radiation hazard to humans and their habitats throughout the entire chain of production and use of building materials for the construction of residential, administrative and industrial buildings. In order to reduce the factors of the negative impact of man-made radiation background on a person it is possible on the basis of studies of the radiation characteristics of building materials and raw materials for their manufacture, to identify sources of NRN in the chain from rocks to industrial production. In turn, the completeness and validity of the results is possible only on the basis of a comprehensive geo-environmental assessment of the radiation hazard characteristics of building materials and raw materials for their manufacture, which will reduce the negative impact on the ecology of the human environment through the use of "radiationfriendly" materials.
\end{abstract}

\section{Introduction}

As a result of anthropogenic environmental factors studies, scientists established the significance of the radiation factor due to the natural background, radiation background from natural radionuclides and artificial background [1-3]. The influence of this factor is intensifying in the light of global changes in the human environment, including through the increasing use of natural resources, changing landscapes, urbanization, etc. etc., which in turn requires finding a reasonable compromise in terms of preserving the well-being of the population, nature and industrial production [1-4].

The man-made radiation factor has the greatest impact on humans and their habitats due to the content of the NRN in the rocks, which are the main raw materials for the production

\footnotetext{
* Corresponding author: dn89@bk.ru
} 
of building materials. The radioactivity of rocks is due to the presence in them of long-lived radionuclides belonging to the families of uranium-238 (238U), and thorium-232 (232Th) with daughter decay products and potassium-40 (40K). Radiation hazards to humans in these chains have mainly radiation from the decay products: radionuclides -226 (226Ra), radon-222 (222Rn) and radon (toron) -220 (220Rn) [4.5-10].

Studies of the radioactivity of various building materials show a significant variation in the numerical values of the NRN [10-17]. The illustration is the data given in table 1.

Table 1. The specific activity of the NRN for some building materials and raw materials.

\begin{tabular}{|c|c|c|c|}
\hline Material & ${ }^{226} \mathrm{Ra}, \mathrm{Bq} / \mathrm{kg}$ & ${ }^{232} \mathrm{Th}, \mathrm{Bq} / \mathrm{kg}$ & ${ }^{232} \mathrm{Th}, \mathrm{Bq} / \mathrm{kg}$ \\
\hline Concrete & $22-53$ & $16-59$ & $226-826$ \\
\hline Lightweight concrete & $20-60$ & $15-40$ & $62-430$ \\
\hline Brick & $10-91$ & $9-73$ & $3-675$ \\
\hline Ash & $62-706$ & $15-112$ & $185-940$ \\
\hline Dry mixes & $18-33$ & $7-36$ & $49-444$ \\
\hline Natural stones & $18-74$ & $18-60$ & $65-921$ \\
\hline Sand & $8-30$ & $3-30$ & $47-444$ \\
\hline Ceramic tile & $31-61$ & $37-66$ & $310-600$ \\
\hline Blast furnace slag & $42-270$ & $19-70$ & $133-240$ \\
\hline
\end{tabular}

Therefore, from the point of view of science and practice, the data on the content of NRN in nature have the great importance, i.e. data on the abundance of elements whose isotopes determine the natural radioactivity of rocks, and as a result, the NRN content in building materials and raw materials. The most detailed data is considered in practice [18] and is given as an example in Table 2 .

Table 2. Data on the content of elements in rocks of various types, (wt.\%).

\begin{tabular}{|c|c|c|c|c|c|c|c|c|c|c|}
\hline \multirow[t]{3}{*}{$\begin{array}{c}\text { Elem } \\
\text { ent }\end{array}$} & \multicolumn{5}{|c|}{ Igneous rocks } & \multicolumn{3}{|c|}{ Sedimentary rocks } & \multicolumn{2}{|c|}{$\begin{array}{c}\text { Deep sea } \\
\text { precipitation }\end{array}$} \\
\hline & \multirow{2}{*}{$\begin{array}{l}\text { Ultra } \\
\text { basic }\end{array}$} & \multirow{2}{*}{$\begin{array}{l}\text { Bas } \\
\text { alt }\end{array}$} & \multicolumn{2}{|c|}{ granitoids } & \multirow{2}{*}{$\begin{array}{l}\text { Sye } \\
\text { nite }\end{array}$} & \multirow[t]{2}{*}{ clay } & \multirow[t]{2}{*}{ sandy } & \multirow{2}{*}{$\begin{array}{l}\text { Carbo } \\
\text { nate }\end{array}$} & \multirow{2}{*}{$\begin{array}{l}\text { calcar } \\
\text { eous }\end{array}$} & \multirow{2}{*}{$\begin{array}{l}\text { claye } \\
\text { y }\end{array}$} \\
\hline & & & $\begin{array}{l}\text { Rich } \\
\mathrm{Ca}\end{array}$ & $\begin{array}{l}\text { Poor } \\
\mathrm{Ca}\end{array}$ & & & & & & \\
\hline$\overline{\mathrm{K}}$ & $\begin{array}{l}4.10^{-} \\
3\end{array}$ & $\begin{array}{l}8,3 \\
10^{-1}\end{array}$ & 2,52 & 4,2 & 4,8 & 2,66 & 1,07 & $\underset{-1}{2,7.10}$ & $2,9.10$ & $2,5.10$ \\
\hline Th & $\begin{array}{l}4.10^{-} \\
7\end{array}$ & $\begin{array}{l}4.10 \\
-4\end{array}$ & $\begin{array}{l}8,5.10 \\
-4\end{array}$ & $\begin{array}{l}1,7.1 \\
0^{-3}\end{array}$ & $\begin{array}{l}1.3 \\
10^{-3}\end{array}$ & $\begin{array}{l}1,2 \\
10^{-3}\end{array}$ & $\begin{array}{l}1,7.10 \\
-4\end{array}$ & $\begin{array}{l}1,7.10 \\
-4\end{array}$ & n. $10^{-4}$ & n. $10^{-4}$ \\
\hline$\overline{\mathrm{U}}$ & $1.10^{-}$ & $1_{-4}^{1.10}$ & $3.10^{-4}$ & $3.10^{-}$ & $\begin{array}{l}3.10 \\
-4\end{array}$ & $\begin{array}{l}3,7 \\
10^{-4}\end{array}$ & $\begin{array}{l}4,5.10 \\
-4\end{array}$ & $\underset{-4}{2,2.10}$ & n. $10^{-5}$ & ${ }_{-4}^{1,3.10}$ \\
\hline
\end{tabular}

The data presented clearly shows a significant variation in $2,3,4$ orders of magnitude in the weight content of elements for different types, classes and origins of rocks. These facts, on the one hand, explain the difference in the NRN content in building materials and, on the other hand, allow us to establish a relationship between the origin of raw materials and the specific activity of the NRN in building materials, which in turn allows us to purposefully create "radiation-friendly" building materials.

\section{Techniques and objects of a research}

The results of previous studies have shown that the content of various radionuclides in rocks differs significantly depending on their type, origin and structure of formation of 
rocks. In addition, industry, additives and artificial materials are used for the production of some building materials. Recently, a huge amount of building materials, origin and raw materials for manufacturing, which are not always determined, have appeared on the Russian market. The raw materials may contain radionuclides of technogenic origin, formed due to accidents at facilities and uncontrolled release of technogenic radionuclides (TRN) into the environment.

Known methods do not allow a comprehensive assessment of the radiation hazard of the use of rocks in the production of building materials. At the same time, a geoecological assessment of natural and man-made radionuclides entering building materials throughout the production chain from rocks to industrial production will reduce the negative impact on the human environment ecology through the use of "radiation-friendly" materials.

"Radiation-friendly" materials include materials with the lowest radionuclide content (radium 226, thorium 222, potassium 40, cesium 137) [19, 20]. This is feasible in the development of an integrated methodology for assessing radiation parameters in the production and use of building materials, which will lead to the creation of an environmentally safe and comfortable environment in the places where people live.

The main purpose of the method is to obtain complete and scientifically based information on radiation factors affecting humans and the environment during the extraction of raw materials, the manufacture and use of materials based on rocks. The technique considers not only the process of justifying and selecting radiation-friendly materials using new extraction of natural resources - the main branch (RESOURCES), but also the use of previously secondary resources - a side branch (WASTE). The catastrophic accumulation of industrial waste, including construction waste, also requires their involvement in the production of building materials. This reduces the burden on the natural environment, since previously extracted and used natural resources are included in the turnover. Block diagram, sequence and stages content are shown on the picture 1 .

The method of geoecological assessment of the radiation hazard of using rocks in the production of building materials consists of the following steps:

\section{$1^{\text {st }}$ stage}

RESOURCES: Extraction of new resources from the natural environment. Pre-selection and evaluation of components of raw materials based on theoretical data for the design of new building materials, taking into account the types of rocks. Raw materials for the construction industry.

WASTE: The use of industrial waste, waste rock in the extraction of minerals, the reuse of materials from the construction industry, including the demolition of buildings and structures.

$\mathbf{2}^{\text {nd }}$ stage - Potential danger (safety)

RESOURCES: Estimates of potential hazard, taking into account radiation factors for various applications in civil and industrial construction.

WASTE: Analysis of possible use of secondary resources. 


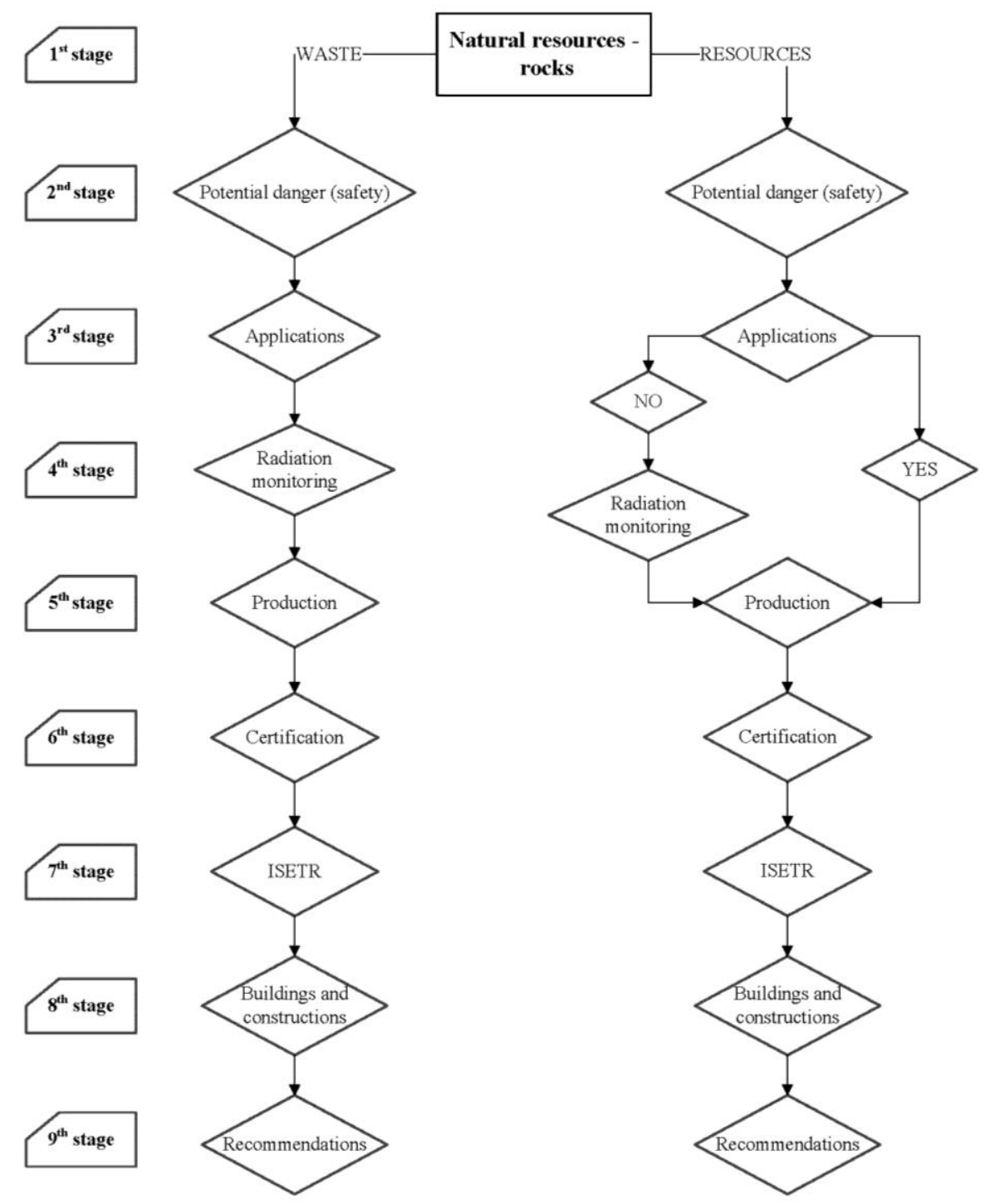

Fig. 1. Block diagram. Sequence and stages content.

$3^{\text {rd }}$ stage - Applications

RESOURCES: Classification of scopes based on potential hazards. Initial rejection of raw materials and components of materials. Classes and types of raw materials are determined that can be used without studying radiation factors (YES) or further studies are needed (NO).

WASTE: Rejection of secondary resources and raw materials for construction materials, such as thorium sands, waste rock from uranium mining, building structures during the dismantling of nuclear facilities, etc.

$4^{\text {th }}$ stage - Radiation monitoring 
Work on stage 4 is associated with high financial costs and require high qualifications from the researchers.

RESOURCES: Rationale for the need and scope of experimental control of the NRN and TR. The choice of the necessary and sufficient number of controlled radiation parameters: the specific and total activity of the NRN, the radon flux density (RFD), the dose equivalent rate (ER). Methodical and instrumental support of radiation monitoring.

WASTE: Mandatory and complete control of all radiation parameters

$5^{\text {th }}$ stage - Production

RESOURCES: Management of radiation characteristics in the production of materials for construction products. Recommendations on the composition of the production of materials and applications.

WASTE: Management of radiation characteristics in the production of materials with the rationale for the possibility of the dilution method (use as part of the raw material component with a high content of NRN). Recommendations on the composition of the production of materials and applications.

\section{$6^{\text {th }}$ stage - Certification}

RESOURCES: Materials class definition. Passports of radiation quality materials. The need to control the equivalent dose rate and radon activity in residential and industrial buildings. Justification of the possibility of only calculated studies of radiation factors in residential and industrial buildings.

WASTE: Materials class definition. Passports of radiation quality materials. Mandatory control of all radiation parameters in residential and industrial buildings.

\section{$\mathbf{7}^{\text {th }}$ stage - ISETR}

RESOURCES: Filling the information system on natural and man-made radioactivity (ISETR) for users in the design and selection of areas for the use of building materials. Ensuring the possibility of excluding intermediate stages 2-6 for the User in the chain Manufacturer, Designer, Builder, Consumer.

WASTE. Filling the information system on natural and man-made radioactivity (ISETR) for users in the design and selection of areas for the use of building materials. Restrictions on the use of building materials based on secondary resources.

$8^{\text {th }}$ stage - Buildings and constructions

RESOURCES: The use of simplified radiation monitoring of DER in new construction sites.

WASTE: Radiation monitoring in full volume.

$9^{\text {th }}$ stage - Recommendations

RESOURCES: Using of information for scientific and technical justification of adjusting regulatory and technical documentation to reduce the negative impact on the environment of the human environment through the use of radiation-friendly building materials and products from them.

WASTE: Use of information for a scientific and technical justification for limiting the use of certain types of secondary raw materials in the construction industry.

The developed methodology is based on the Russian concept and criteria, as well as international evaluation criteria, recommendations in the field of limiting the exposure of the population from natural sources, the parameters used for these purposes and experimental methods. 


\section{Analysis and summery}

The use of the technique in practice is illustrated by the examples below. Materials such as brick, concrete, which form the basis of each building, and finishing materials that are used for interior decoration were investigated. That is, the materials directly affecting the environmental and radiation component of the dwelling. Among the finishing materials were considered tiles, dry mixes, putties and various adhesives. In total, several dozen samples of building materials were prepared for research.

Figure 2 shows the maximum values of the data obtained by type of building materials.
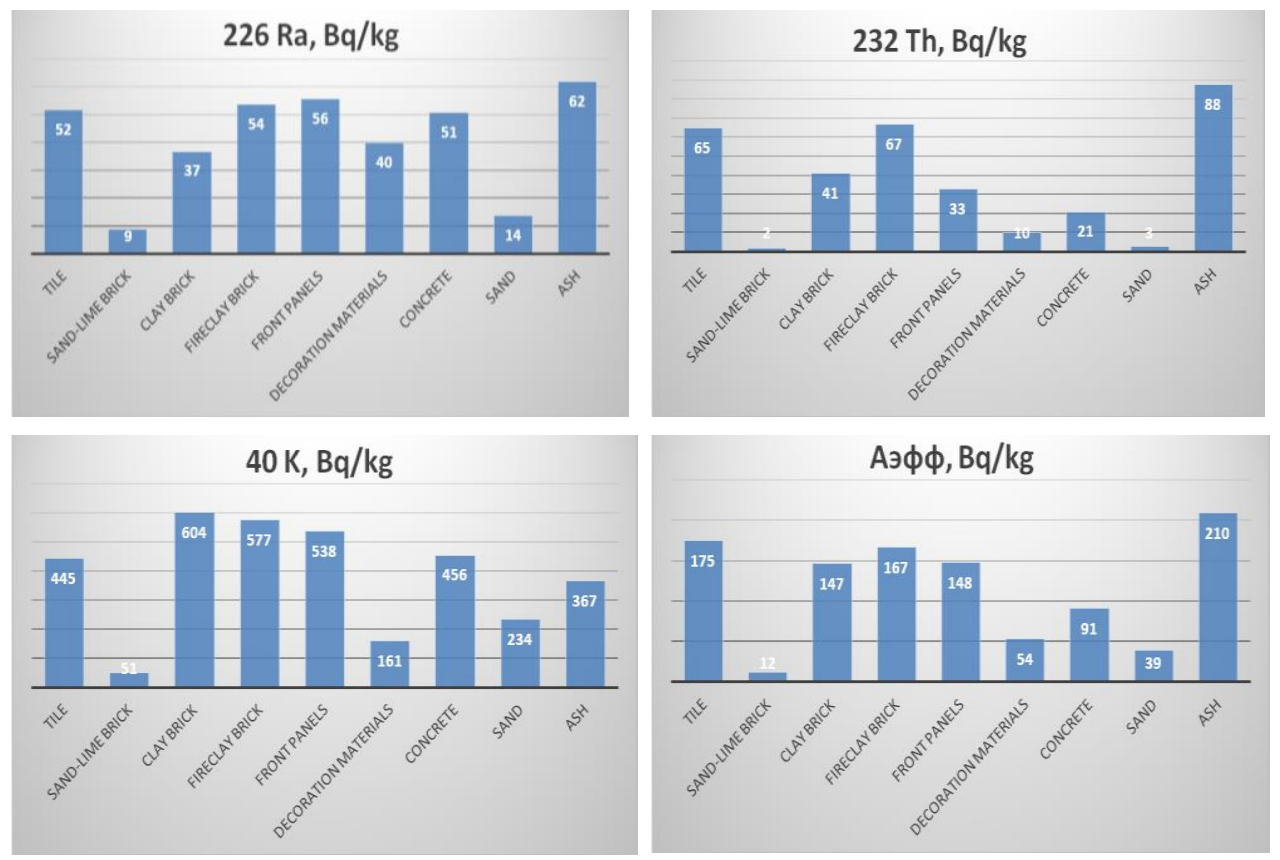

Fig. 2. Specific and effective activity of NRN for various types of building materials and raw materials for their manufacture.

Analysis of the obtained results showed that the presented materials do not exceed allowed value of the specific effective activity, and they belong to the 1st class of radiation safety [21], i.e. they can be used without restrictions. Ceramic materials, brick and ash have the highest NRN content. Comparison of experimental data with calculated ones based on the European approach [1-2] on the so-called radiation factor for the materials considered leads to similar conclusions. Table 3 shows the corresponding results. At the same time, for other materials and with different EPN content in the materials, the results show limitations in the application of the European approach [19-20]. 
Table 3. Justification for the use of typical building materials in accordance with the Russian and European approaches.

\begin{tabular}{|l|l|l|}
\hline Building material & Do not exceed control values & Excess reference values \\
\hline Concrete & Perhaps, but control is necessary & $\begin{array}{l}\text { Perhaps when using highly } \\
\text { radioactive materials }\end{array}$ \\
\hline Clay bricks & Perhaps, but control is necessary & $\begin{array}{l}\text { Perhaps when using highly } \\
\text { radioactive materials }\end{array}$ \\
\hline Sand-lime bricks & In most cases & Little likely \\
\hline Tile & Perhaps, but control is necessary & $\begin{array}{l}\text { Constant monitoring is required, } \\
\text { highly radioactive additives are } \\
\text { used }\end{array}$ \\
\hline
\end{tabular}

Conducted theoretical and experimental studies revealed the relationship of controlled radiation parameters, such as specific and total effective activity of the ERN (Aeff), equivalent dose rate (DER) and radon flux density (RFD) between the origin and types of basic building materials and raw materials for their manufacture. It has been found that for most materials there is a relationship with data on the prevalence of $\mathrm{U}-{ }^{226} \mathrm{Ra}$ and $\mathrm{K}-{ }^{40} \mathrm{~K}$. In the case of $\mathrm{Th}-{ }^{232} \mathrm{Th}$, there is no unambiguous connection. In these cases, this indicates the need for experimental studies of raw materials and the technology of making ceramic materials and ash in which the raw materials are fired, and, therefore, the concentration of radioactive elements increases.

Table 4 presents the averaged experimental data on the magnitude of the monitored parameters for building materials and products from them.

Table 4. Averaged values of equivalent dose rate and radon flux density in building materials.

\begin{tabular}{|l|c|c|c|c|c|c|}
\hline Name of building material & ${ }^{{ }^{226} \mathbf{R a}}$ & ${ }^{\mathbf{2 3 2}} \mathbf{T h}$ & ${ }^{\mathbf{4 0}} \mathbf{K}$ & $\begin{array}{c}\mathbf{A}_{\text {eff }}, \\
\mathbf{B q} / \mathbf{k g}\end{array}$ & $\begin{array}{c}\mathbf{M E D}, \\
\boldsymbol{\mu S v} / \mathbf{h}\end{array}$ & $\begin{array}{c}\mathbf{P P R}, \\
\mathbf{m b k} /(\mathbf{s q . m} * \mathbf{s})\end{array}$ \\
\hline Sidewalk tile & 13 & 6 & 127 & 32.5 & 0.17 & 8 \\
\hline Facade tiles & 7 & 6 & 89 & 22.8 & 0.26 & 6 \\
\hline Universal dry mix & 40 & 9 & 38 & 54.6 & 0.20 & 14 \\
\hline Tile adhesive & 12 & 7 & 21 & 22.2 & 0.17 & 8 \\
\hline GS-polystyrene concrete & 12 & 8 & 161 & 37.2 & 0.17 & 16 \\
\hline $\begin{array}{l}\text { Silicate tongue-and-groove } \\
\text { unit }\end{array}$ & 10 & 2 & 43 & 15.8 & 0.16 & 11 \\
\hline Ash & 62 & 88 & 367 & 210.1 & 0.23 & 23 \\
\hline
\end{tabular}

From the presented data, we see that there is a relationship between the content of natural radionuclides and the equivalent dose rate: the higher specific effective activity, the greater dose rate. Between the criterion of natural radioactivity and radon flux density, dependence is mainly observed in bulk materials and with a high content of ${ }^{226} \mathrm{Ra}$, since the inert radioactive gas - radon-222 $\left({ }^{222} \mathrm{Rn}\right)$ is a daughter product of ${ }^{226} \mathrm{Ra}$. 


\section{Conclusion}

1. Complex methodology has been develop for the geo-environmental assessment of the radiation hazard of using rocks in the production of building materials has, which allows theoretically and experimentally to establish relationship and control the radiation parameters of building materials in the chain from mining to production and use.

2. The dependences were investigated and patterns were identified for the distribution of natural radionuclides in building materials during all lifecycle stages: from rocks to building structures of residential and industrial premises.

3. Computational and experimental studies using this technique allow to create an information system on the natural and man-made radioactivity of building materials, the use of which is aimed to provide an environmentally safe and comfortable human environment.

\section{References}

1. IAEA Safety Standards. Radiation Protection and Safety of Radiation Sources: International Basic Safety Standards. General Safety Requirements Part 3 International Atomic Energy Agency, Vienna (2015)

2. European Commission. Radiation protection 112 Radiological Protection Principles concerning the Natural Radioactivity of Building Materials. - Directorate-General Environment, Nuclear Safety and Civil Protection, Luxemburg (1999)

3. The Law of the Russian Federation № 3-FZ dated January 9, 1996. «Radiation Safety of the Population»).

4. E. M. Krisyuk. Background radiation of the facilities. Moscow. Energoatomizdat.. p.120 (1989)

5. O.P. Sidel'nikova Radiatsionnyy kontrol' v stroitel'noy industrii. Moscow, ASV, p. 208 (2002)

6. U.S. Environmental Protection Agency (EPA). Evaluation of EPA's Guidelines for Technologically Enhanced Naturally Occurring Radioactive Materials (TENORM) (2000)

7. NUREG-1501. Background as a Residual Radioactivity Criterion for Decommissioning. - U.S. Nuclear Regulatory Commission Office of Nuclear Regulatory Research Washington, DC 20555-0001 (1994)

8. I.A. Engovatov, D.V. Nikolaeva, Ecol. of Urban Areas. Moscow, 4, 60-66. (2015)

9. D.V. Buzina, I.A. Engovatov, D. D. Nguyen, A. Ovakivean. MATEC Web of Conf. 196, 04064 (2018)

10. S. Fares, Ali. A. M. Yassene, A. Ashour, M. K. Abu-Assy, M. Abd El-Rahman, Nat. Sc. Vol.3, 10, 895-905 (2011)

11. S.A. Akhremenko, Management of radiation quality of building products /S.A. Akhremenko. - M .: ACB, p. 239. (2000)

12. O.P.Sidel'nikova, Yu.D.Kozlov, Inter.-vestnik VolgGASU. Ser.: Politematicheskaya. Volgograd,. Vyp. 2(27) (2013)

13. M. A. M. Uosif Internat. Journ. of u- and e- Service, Scien. and Technol. Vol.7, 2, 6376 (2014) 
14. Y. Raghu, N. Harikrishnan, A. Chandrasekaran, R. Ravisankar, Afric. Journ. of Basic \& Applied Sciences 7 (1): 16-25, (2015)

15. I.A. Engovatov, D.V. Nikolaeva, Estest. and Tekhn. Scien., 11-12, 394-396. (2014)

16. W.R. Alharbi, J.H. AlZahrani, Journ. of Amer. Scien., 8(10), 651-656 (2012)

17. Radiation. Dose, effects and risk. Translation from English - M .: Mir, 79 (1988)

18. G.V. Voytkevich, A.V. Kokin, A.E. Miroshnikov, V.G. Prokhorov, Handbook of geochemistry, - M .: Nedra, 480 (1990)

19. D.V. Buzina, I.A. Engovatov, L.A. Alimov, M.Yu. Slesarev, MATEC Web of Conference 86, 04044 (2016)

20. D.V. Buzina, I.A. Engovatov, IOP Conf. Ser.: Mater. Sci. Eng. 365, 042029 (2018)

21. SanPiN 2.6.1.2523-09 " Radiation safety standards (NRB-99/2009)" 